\section{Economic Effect of Insect Pest Management Strategies on Small-scale Tomato Production in Mississippi}

\author{
Ronald C. Stephenson ${ }^{1}$, Christine E.H. Coker ${ }^{1}$, \\ Benedict C. Posadas ${ }^{1}$, Gary R. Bachman ${ }^{1}$, Richard L. Harkess ${ }^{2}$, \\ John J. Adamczyk ${ }^{3}$, and Patricia R. Knight ${ }^{4}$
}

ADDITIONAL INDEX WORDS. economics, insect, integrated pest management, organic, Solanum lycopersicum, tomato

SuMMARY. Due to difficulty in monitoring insect pests, applications of insecticides are frequently conducted on a calendar schedule. However, seasonal variability in pest populations leads to these calendar schedules sometimes being inaccurate. Threshold-based insect management strategies, including use of thresholds with conventional pesticides and with use of organic pesticides only, were compared with a conventional calendar approach for yield, management cost, and production value of tomato (Solanum lycopersicum). Effect of cultivar was considered by inclusion of the long season cultivar Celebrity and the short season cultivar Early Girl Bush. These factors were compared for spring and fall seasons during two production years. Greatest total and marketable yields were obtained from use of conventional pesticides according to action thresholds. Use of organic insecticides according to thresholds did not affect yields in comparison with a calendar-based approach. Proportion of fruit rated unmarketable was greater with use of organic insecticides due to reduced efficacy and residual of control. Production costs for the organic threshold-based approach were greater due to increased number of insecticide applications required. Gross margin for both conventional and organic thresholdbased insect pest management was greater than for the conventional calendar method. Increased economic return for conventional threshold-based management was due to increased yields. Increase in return for organic threshold management was based on premiums received for organically grown tomatoes. Adoption of conventional threshold-based insect pest management by small-scale producers has the potential to increase production efficiency and value, as well as increase environmental sustainability of production. Economic feasibility of organic production requires access to markets willing to pay significant premiums for organic produce. Further research to evaluate economic and yield impacts of production practices for small-scale farms is needed.

$\mathrm{T}$ omatoes were produced on 546 farms in Mississippi in 2012 , with a total production of 339 acres. Greenhouse production

Received for publication 14 June 2019. Accepted for publication 1 Nov. 2019.

Published online 5 December 2019.

${ }^{1}$ Coastal Research and Extension Center, Mississippi State University, 1815 Popps Ferry Road, Biloxi, MS 39532

${ }^{2}$ Department of Plant and Soil Sciences, Mississippi State University, Box 9555, Mississippi State, MS 39762

${ }^{3}$ U.S. Department of Agriculture, Agricultural Research Service, Thad Cochran Southern Horticulture Research Laboratory, 810 MS-26, Poplarville, MS 39470

${ }^{4}$ South Mississippi Branch Experiment Station, Mississippi State University, P.O. Box 193, Poplarville, MS 39470

R.C.S. is the corresponding author. E-mail: c.stephenson@ msstate.edu or ronaldcstephenson@gmail.com.

This is an open access article distributed under the CC BY-NC-ND license (https://creativecommons.org/ licenses/by-nc-nd/4.0/).

https://doi.org/10.21273/HORTTECH04435-19 of tomatoes accounts for a further 83 farms and 6.05 acres [U.S. Department of Agriculture (USDA), 2017]. Based on these data, $86 \%$ of tomato production in Mississippi is conducted in the field. Average tomato production area per farm is 0.57 acres. Of farms reporting tomato production, $47.3 \%$ were smaller than 0.49 acres, and only $8.8 \%$ of farms were larger than 0.99 acres (Posadas, 2018a). Tomatoes were produced on $40.4 \%$ of vegetable farms, with production constituting $\approx 0.9 \%$ of total vegetable production area (USDA, 2017).

Insect pests have a significant effect on crop yields and quality. In crops with extensive pesticide use and cultivars with resistance to insect and disease, losses have been estimated between $20 \%$ and $30 \%$ of total yield (Lucas, 2011). Information on degree of damage resulting from insect pressure in small-scale vegetable production is limited. Lack of access to restricted use pesticides and cultivars with limited resistance to insect and disease may result in extensive losses. Improved crop protection strategies may lead to significant increases in production efficiency (Lucas, 2011).

Due to difficulty in monitoring for pests for threshold-based approaches, applications of insecticides are frequently conducted on a calendar schedule. However, variability in pest populations leads to inaccuracy and ineffectiveness of applications. Improperly timed pesticide applications are both expensive and may worsen problems by affecting beneficial insect species without effectively controlling the target pest (Herms, 2004). Concern regarding impacts of pesticides on the environment and human health has led to development of integrated pest management (IPM) programs. These programs involve use of observation of pest populations in the field to direct timing of pesticide applications. Central to the concept of IPM is use of an economic threshold of a population level where application of a pesticide is advisable. IPM programs have been widely successful in reducing pesticide use while increasing profitability of crop production (Allen and Rajotte, 1990). Economic thresholds require an understanding of crop market value. Because of unpredictability and variability of markets, economic thresholds can be difficult to apply. As a result, action thresholds have been developed as levels of pest density that

\begin{tabular}{llll}
\hline $\begin{array}{l}\text { Units } \\
\text { To convert U.S. to SI, } \\
\text { multiply by }\end{array}$ & U.S. unit & SI unit & $\begin{array}{l}\text { To convert SI to U.S., } \\
\text { multiply by }\end{array}$ \\
\hline 0.4047 & acre $(\mathrm{s})$ & $\mathrm{ha}$ & 2.4711 \\
7.8125 & $\mathrm{fl} \mathrm{oz} / \mathrm{gal}$ & $\mathrm{mL} \cdot \mathrm{L}^{-1}$ & 0.1280 \\
0.3048 & $\mathrm{ft}$ & $\mathrm{m}$ & 3.2808 \\
3.7854 & gal & $\mathrm{L}$ & 0.2642 \\
2.54 & inch(es) & $\mathrm{cm}$ & 0.3937 \\
0.4536 & $\mathrm{lb}$ & $\mathrm{kg}$ & 2.2046
\end{tabular}


result in loss of crop quantity or quality (Schuster and Smith, 2015).

In comparison with average pesticide use in agriculture, applications of pesticides by fruit and vegetable producers was seven times greater (Fernandez-Cornejo, 1996). Vegetable producers are required to produce high yields as well as avoid losses in crop quality caused by pests because of a lack of tolerance for blemishes by consumers (Lamichhane et al., 2016). High investments in crops and high-quality standards have led to large numbers of pesticide applications and increased labor costs for fruit and vegetable production (Picanço et al., 2007). Adoption of IPM in these crops may lead to significant reductions in pesticide applications without damage to yield quantity or quality (Picanço et al., 2007). Because of its roots in entomology, the primary criterion used for adoption of IPM has been use of action thresholds and pest population monitoring in making decisions to apply pesticides (Kogan, 1998).

Organic vegetables represent an increasingly important segment of the vegetable production sector. The market for organic foods has increased at an annual rate of $20 \%$ to $30 \%$ in the United States and Europe (Barker and Sorenson, 2003). Consumers concerned with pesticide residues perceive organic products as offering a choice lower in or free from pesticide residues (DeLind, 2011). Efficacy for synthetic pesticides is often greater than organic controls. When management practices were investigated, type of pesticide used was the most important factor affecting insect populations (Hummel et al., 2002). A thorough understanding of crop and pest ecology and use of multiple control strategies is essential for effective control of insect pest populations under organic standards (Pujari et al., 2013). Buildup of insect pests is particularly problematic in organic production; however, use of synthetic pesticides may result in long-term problems, such as development of resistance in both insect pest and pathogen populations and elimination of natural enemies that may otherwise control pests (Hummel et al., 2002).

Morphological and physical characteristics of plants are associated with attraction, feeding, and oviposition of insect pests (Saberfar and Sheikhi, 2009). Thus, plant phenology may influence pest populations because of factors such as maturation date, which vary according to plant cultivar. In addition, pest population development is favored by high temperatures and plant cultivars that vary in their development time may experience differing levels of pest pressure (Yurk and Powell, 2010). Under field conditions, temperature and relative humidity have been shown to affect populations of tomato pests such as aphids (Aphidoidea) and whiteflies (Aleyrodidae) (Waluniba and Alemla Ao, 2014).

The objective of this study was to evaluate the effect of alternative insect pest management strategies on the economic return of small-scale tomato production. Strategies considered in this study were management based on a calendar spray schedule, conventional pesticide management based on action thresholds, and management based on action thresholds using organic controls.

\section{Materials and methods}

Three insect management strategies were evaluated on two cultivars of tomato commonly available to growers in south Mississippi. In the first treatment (Calendar), conventional insecticides were applied every $14 \mathrm{~d}$ after transplantation regardless of observed insect pest populations. This schedule was based on observations of pesticide application practices by producers in Mississippi. In the second treatment (Conventional Threshold), conventional pesticides were applied when sampled insect populations were greater than established action thresholds (Table 1). The third treatment (Organic Threshold) uses action thresholds; however, pesticides used in this treatment were limited to those allowed in organic production (USDA, 2016a).

Tomato cultivars for this study included Celebrity and Early Girl Bush. These cultivars were transplanted into raised beds 15 Apr. 2014 and 18 Apr. 2015 for spring seasons and 15 Aug. 2014 and 17 Aug. 2015 for fall seasons. These planting dates are in accordance with recommendations provided by the Mississippi State University Extension Service for planting tomato transplants for locations used in this study (Nagel et al., 2014). Plants were obtained as seed (Harris Seeds, Rochester, NY) and grown under greenhouse conditions at the South Mississippi Branch Experiment Station, Poplarville, MS, before transplantation to raised beds.

Plots were established at four locations in southern Mississippi: 1) Kiln, MS; 2) South Mississippi Branch Experiment Station in Poplarville, MS; 3 ) Beaumont Horticultural Unit in Beaumont, MS; and 4) Stone County USDA Research Station located near Wiggins, MS. Six plots were established at each study location consisting of each of three treatments on two cultivars on which these management practices were evaluated arranged in a randomized complete block design. Study locations served as replications for analysis for a total of four replications. Raised beds were used to reduce effect of location and standardize treatment of plots. Due to flooding and high disease pressure, the Stone County USDA Research Station in Wiggins was not used after Spring 2014.

Plots for this study consisted of two 6 - $\mathrm{ft} \times 6$ - $\mathrm{ft} \times 8$-inch raised beds, constructed from four 2 -inch $\times 8$ inch $\times 6$-ft boards. Each plot consisted of eight plants total. Tomato were planted on 24-inch centers. Plots were arranged in a grid with 6 $\mathrm{ft}$ between individual beds. Growing media in each box consisted of composted pine bark screened to $1 \mathrm{~cm}$ (Eakes Nursery Materials, Seminary, MS). Before planting in each season, media from raised beds were sampled and submitted for testing at the Mississippi State University Soil Testing Laboratory. Recommendations for fertilization and lime application for tomato obtained from the soil testing laboratory of Mississippi State University Extension were followed. In Feb. 2014 and 2015, 1.1 lb $10 \mathrm{~N}-5.7 \mathrm{P}-10.8 \mathrm{~K}$ fertilizer, and $0.33 \mathrm{lb} 34 \mathrm{~N}-0 \mathrm{P}-0 \mathrm{~K}$ fertilizer (Pennington Seed, Madison, GA) were applied to each plot. In addition, $4 \mathrm{lb}$ agricultural lime was applied to each plot before planting in 2014 (Pennington Seed). Fertilization in Aug. 2014 and Aug. 2015 was conducted with $1 \mathrm{lb} 10 \mathrm{~N}-5.7 \mathrm{P}-10.8 \mathrm{~K}$ fertilizer and $0.25 \mathrm{lb} 0 \mathrm{~N}-0 \mathrm{P}-49.8 \mathrm{~K}$ fertilizer for each plot (Voluntary Purchasing Group, Bonham, TX). In all seasons, plants were side-dressed with $0.33 \mathrm{lb}$ 
Table 1. Action thresholds and insecticide recommendations applied for observed insect pests of tomato compiled from extension publications for the southeastern United States.

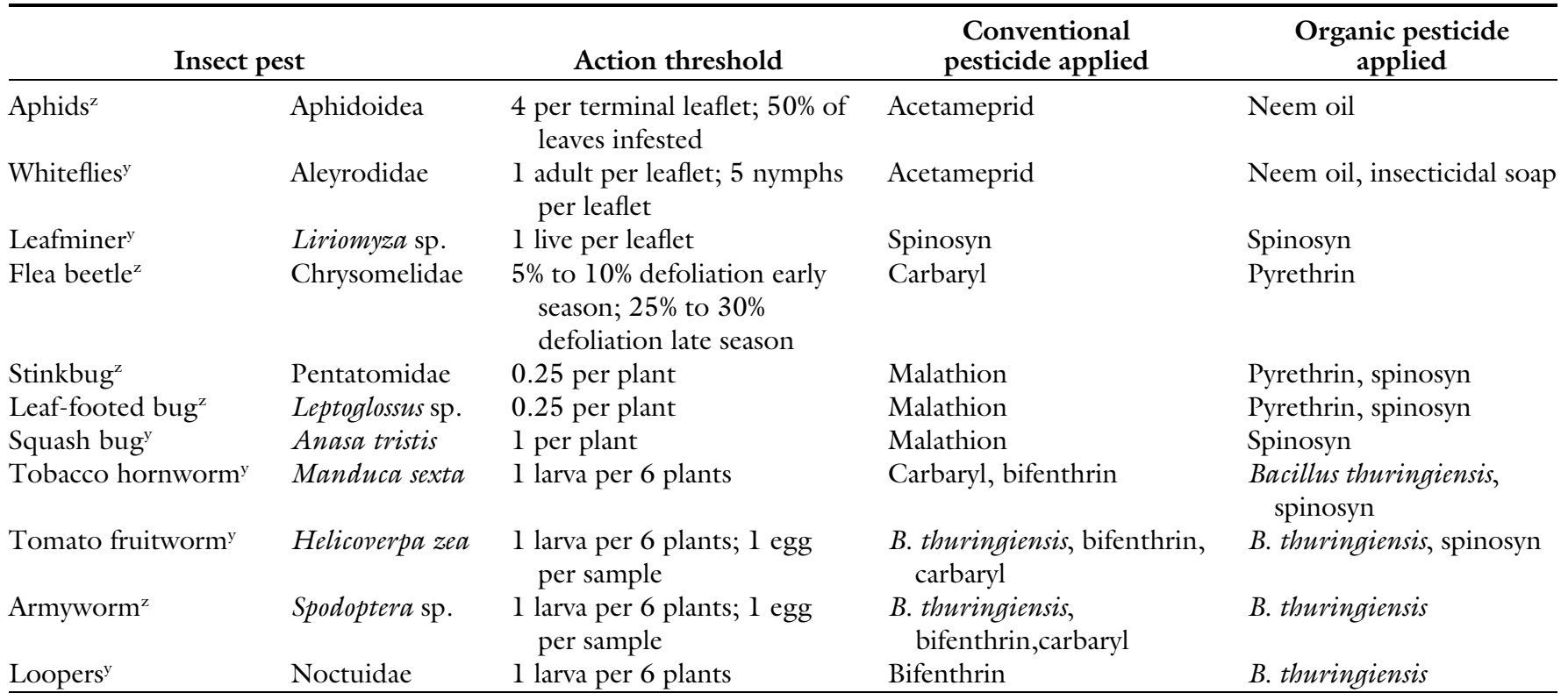

${ }^{\mathrm{z}}$ Majumdar et al. (2014).

${ }^{y}$ Schuster and Smith (2015).

$33 \mathrm{~N}-0 \mathrm{P}-0 \mathrm{~K}$ fertilizer applied to each plot.

Pesticides applied in this study were limited to those commercially available without a Private or Commercial Pesticide Applicator's license, as this is reflective of the purchasing practices for many small-scale producers in Mississippi. Frequently, insecticide purchases are made from local retailers, limiting small-scale producers to similar insecticides as used in home horticulture. In the calendar spray treatment, carbaryl (Sevin; Bayer Environmental Science, Research Triangle Park, NC) in a liquid formulation was applied every 2 weeks after planting according to label instructions (Table 1). This insecticide was chosen because of its broad availability, common use, and activity against a wide range of insect pests.

For the conventional threshold treatment, pesticide applications were conducted as dictated by pest populations. Pesticides used for this treatment were selected according to recommendations issued by the Mississippi State University Extension Service (Layton, 2016). Similar recommendations were followed for organic threshold treatment plots. Because of lack of published action thresholds specific to Mississippi, threshold data and scouting methodology published for other states in the southeastern United States were used (Majumdar et al., 2014; Schuster and Smith, 2015) (Table 1). Pesticides for conventional and organic threshold treatments were applied at label rates (Table 2). Sampling of plots for insect pest populations was conducted weekly and consisted of whole plant visual examinations of four randomly selected plants per plot with attention paid to plant parts as necessary to determine whether action thresholds were reached.

All plots for this study were sprayed prophylactically for common fungal diseases using broad-spectrum fungicides every $7 \mathrm{~d}$. Fungicide applications alternated among myclobutanil (Spectracide Immunox Multi-Purpose Fungicide Spray Concentrate for Gardens; Spectrum Group, St. Louis, $\mathrm{MO}$ ), chlorothalonil (Ferti-lome Broad Spectrum Landscape and Garden Fungicide; Voluntary Purchasing Group), and copper octanoate (Copper fungicide; Bonide Products, Oriskany, NY). Fungicides were used in rotation in the order listed previously so as not to exceed allowable yearly rates and following label instructions.

To evaluate economic benefit of management strategies, cost of inputs was recorded. Cost of all pesticide treatments was calculated by measuring volume of pesticides applied. To accurately measure amount of pesticides applied, average output from a 2-gal pump sprayer (Chapin International, Batavia, NY) over a period of $1 \mathrm{~min}$ was determined. Time spent applying pesticides to plots was recorded and actual volume applied calculated. Pesticide costs were calculated by taking the volume applied as a proportion of total package volume multiplied by package retail price. Retail price was determined based on advertised prices of home use formulations of pesticides advertised by major retailers (Table 2 ). Time spent in managing each treatment was measured and recorded. Activities in which time was recorded include sampling insect populations in conventional threshold and organic treatments, and pesticide application. Because sampling for insect pest populations was not required for management of calendar spray treatments, time spent sampling in these plots was not included in management cost. Value of time worked was calculated from hourly wage data obtained from the Bureau of Labor Statistics. According to the Bureau of Labor Statistics, average wage for an agricultural worker in 2014 and 2015 was $\$ 9.63$ and $\$ 9.66$ per hour, respectively (Bureau of Labor Statistics, 2015). 
Fruit were harvested from plots twice weekly. Harvest from all plots was conducted from 20 June 2014 to 25 July 2014 and from 15 June 2015 to 26 July 2015 in spring seasons. During fall seasons, harvest from all plots was conducted from 26 Oct. 2014 to 17 Nov. 2014 and from 30 Oct. 2015 to 20 Nov. 2015. Fruit harvested in each plot was weighed and rated as marketable or unmarketable. Fruit were rated as unmarketable because of mechanical, disease, or insect injury. Fruit with minor cosmetic damage in accordance with standard quality common for sale at farmers markets or farmstands were considered marketable. Weights and number of fruit were recorded for marketable, unmarketable, and total yield.

Value of fruit was calculated using averages available from the $\mathrm{Na}-$ tional Fruit and Vegetable Retail Report of the USDA-Agricultural Marketing Service (AMS). Values for on-the-vine tomatoes were used, as these prices represent tomatoes harvested as breakers, which most closely represents harvesting conducted in this study (USDA, 2016b). Prices for the 2014 and 2015 seasons are shown in Figs. 1 and 2, respectively. Use of actual prices as reported by the USDA-AMS allow for the impact of price premiums for out-of-season production to be considered. Cost of management practices was subtracted from total marketable yield value for each plot to obtain actual value of production.

The empirical model used in measurement of factors affecting marketable yield, unmarketable yield, cost of insect pest management, gross value, and gross margin is as follows (Eq. [1]):

$$
\begin{aligned}
\mathrm{Y}= & \beta 1 \text { week }+\beta 2 \text { year }+\beta 3 \text { location } \\
& +\beta 4 \text { season }+\beta 5 \text { cultivar } \\
& +\beta 6 \text { method }+\hat{E}
\end{aligned}
$$

Independent variables were evaluated for the impact on yield, management cost, and value for small-scale tomato production in Mississippi. In Spring 2014 and 2015, there were 17 weeks. In Fall 2014, there were 11 weeks, and in Fall 2015, there were 14 weeks of collection (week $=1,2,3 \ldots \mathrm{n}$, where $\mathrm{n}=$ number of weeks in each

Table 2. Retail price of pesticides as advertised by major retailers and cost per minute of application at label rate with 2 -gal $(7.6 \mathrm{~L})$ pump sprayer.

\begin{tabular}{lccc}
\hline Insecticide & $\begin{array}{c}\text { Retail price } \\
(\$)\end{array}$ & $\begin{array}{c}\text { Avg cost as applied } \\
(\$ / \text { min })\end{array}$ & $\begin{array}{c}\text { Rate applied } \\
(\text { fl oz/gal })^{\mathbf{z}}\end{array}$ \\
\hline Carbaryl & $16.05^{\mathrm{y}}$ & 0.17 & 1.5 \\
Malathion & $16.55^{\mathrm{x}}$ & 0.32 & 2.0 \\
Bifenthrin $^{\mathrm{x}}$ & $11.74^{\mathrm{y}}$ & 0.08 & 0.5 \\
Spinosyn $^{\mathrm{w}}$ & $16.99^{\mathrm{x}}$ & 0.25 & 2.0 \\
Bacillus thuringiensis $^{\mathrm{x}}$ & $11.74^{\mathrm{y}}$ & 0.047 & 0.5 \\
Neem oil $^{\mathrm{w}}$ & $10.67^{\mathrm{y}}$ & 0.16 & 2.0 \\
Insecticidal soap $^{\mathrm{w}}$ & $11.90^{\mathrm{y}}$ & 0.21 & 2.5 \\
Pyrethrin $^{\mathrm{w}}$ & $18.50^{\mathrm{v}}$ & 0.08 & 1.4 \\
Acetamiprid $^{\mathrm{y}}$ & $14.49^{\mathrm{x}}$ & 0.27 & 1.5 \\
\hline
\end{tabular}

${ }^{\mathrm{z}} 1 \mathrm{fl} \mathrm{oz} / \mathrm{gal}=7.8125 \mathrm{~mL} \cdot \mathrm{L}^{-1}$.

'Lowe's Companies, Inc. (2014).

${ }^{\mathrm{x}}$ The Home Depot, Inc. (2014).

"Pesticide meets national standards for use in organic production.

vWalmart, Inc. (2014).

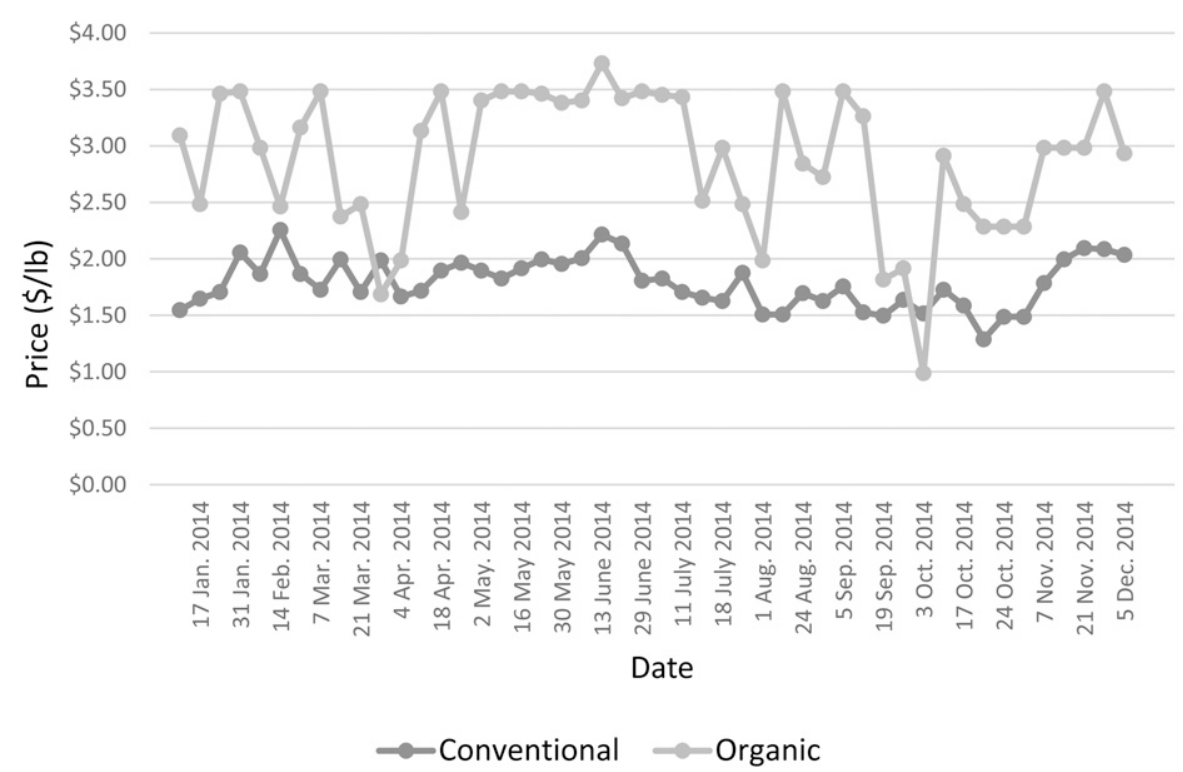

Fig. 1. Retail price of conventional and organic vine ripe tomatoes in 2014 according to the National Fruit and Vegetable Retail Report (USDA, 2016b); $\$ 1.00 / \mathrm{lb}=\$ 2.2046 / \mathrm{kg}$.

season). The 2014 study year served as benchmark for the year variable. The Kiln, MS, site served as the benchmark for location, and spring served as the benchmark season. Benchmark for cultivar was Early Girl Bush and method benchmark was calendar spray.

To determine the significant factors affecting marketable yield, unmarketable yield, cost of insect pest management, gross value, and gross margin, the empirical model defined by Eq. [1] was estimated by using the ordinary least squares procedure in Stata 13 (StataCorp, College Station, $\mathrm{TX})$. The robust variance procedure was used for estimation of regression coefficients. The robust variance procedure results in precise calculations of the sample-to-sample variations of the parameter estimates (Ling, 1994; Posadas, 2018b; Rogers, 1993). The variation inflation factor was calculated to detect the possible presence of multicollinearity. The marginal impacts of the independent variables were computed using the margins procedure of Stata 13.

\section{Results}

EFFeCTS OF CULTIVAR AND PEST MANAGEMENT STRATEGY ON YIELD. Variables included in the empirical model for total yield explained $13.3 \%$ of variation based on linear 
regression analysis. The estimated regression equation was significant as shown by the $\mathrm{F}$ value (Table 3 ). Total yield was not significantly affected by year or season. Though greater yields were obtained from 'Celebrity' than from 'Early Girl Bush' tomato, these differences were not significant. Total yields for the Beaumont Horticultural Unit location were significantly greater than the benchmark. Increased yields at the Beaumont Horticulture
Unit may be attributed by variability in sunlight, temperature, and rainfall between locations. Differences from the benchmark were not observed in other locations in this study. Total yield from the conventional threshold treatment was significantly greater than from the calendar treatment, which served as the benchmark. Total yields from the conventional threshold treatment were $60 \%$ greater than from the calendar treatment. The organic

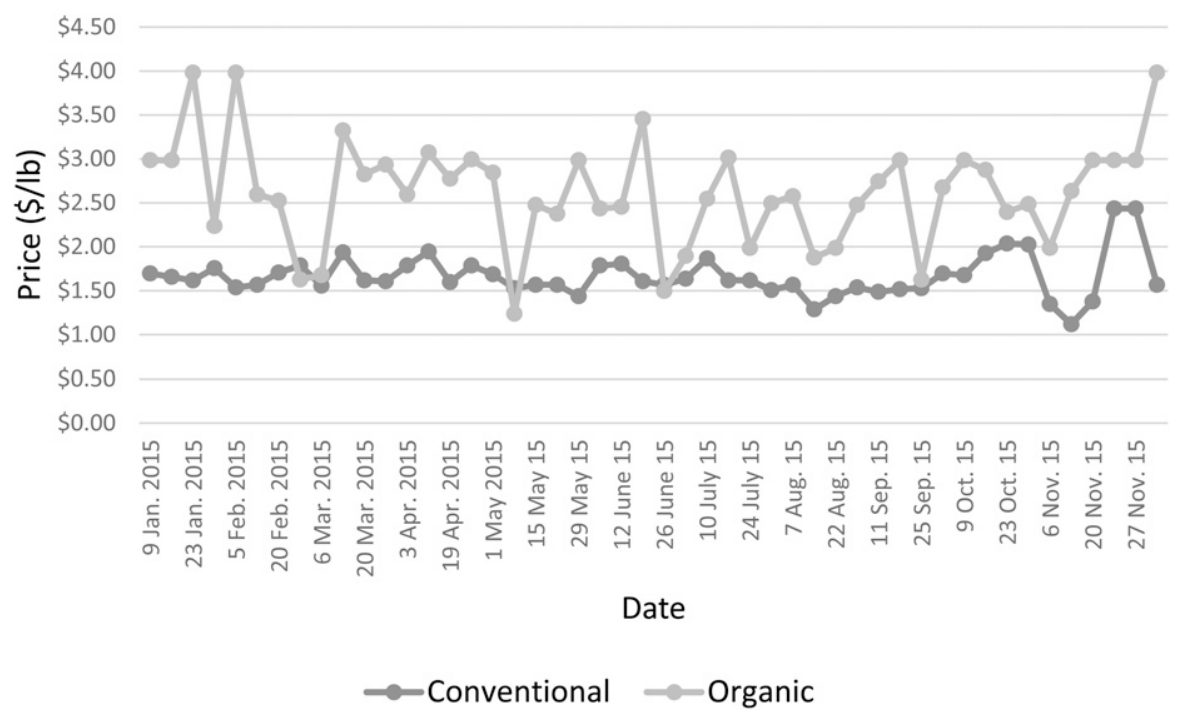

Fig. 2. Retail price of conventional and organic vine ripe tomatoes in 2015 according to the National Fruit and Vegetable Retail Report (USDA, 2016b); $\$ 1.00 / \mathrm{lb}=\$ 2.2046 / \mathrm{kg}$.

Table 3. Effect of sample date, season, production year, location, cultivar, and insect pest control treatment on total yield of 'Early Girl Bush' and 'Celebrity' tomato in small-scale production in Mississippi.

\begin{tabular}{lcc}
\hline Independent variable & Coefficient & Robust SE \\
\hline Week $^{\mathrm{z}}$ & $0.1850^{* * *}$ & 0.0164 \\
Year $^{\mathrm{y}}$ & $0.2801^{\mathrm{Ns}}$ & 0.1609 \\
Location $^{\mathrm{x}}$ & & \\
Poplarville, MS $_{\text {Beaumont, MS }}$ & $0.3254^{\mathrm{Ns}}$ & 0.1828 \\
Wiggins, MS & $0.5676^{* *}$ & 0.2334 \\
Season & $-0.1399^{\mathrm{Ns}}$ & 0.1917 \\
Cultivar & $0.3635^{*}$ & 0.1594 \\
Method & $0.1633^{\mathrm{Ns}}$ & 0.1385 \\
Conventional threshold & & \\
Organic threshold & $0.6002^{* * *}$ & 0.1826 \\
Constant & $0.0287^{\mathrm{Ns}}$ & 0.1388 \\
Observations (no.) & $-1.2592^{* * *}$ & 0.2618 \\
F value & 1,164 & \\
$R^{2}$ & $16.20^{* * *}$ & \\
\hline
\end{tabular}

${ }^{\mathrm{z}}$ There were 17 weeks in Spring 2014 and 2015, 11 weeks in Fall 2014, and 14 weeks in Fall 2015.

${ }^{\mathrm{y}}$ Benchmark year is 2014 .

${ }^{\mathrm{x} B e n c h m a r k}$ location is Kiln, MS

wenchmark season is spring.

${ }^{\vee}$ Benchmark cultivar is Early Girl Bush.

"Benchmark method is Calendar.

NS, ${ }^{*},{ }^{* *},{ }^{* *}$ Nonsignificant or significant at $P \leq 0.05,0.01$, or 0.001 , respectively. threshold treatment did not result in greater total yields (Table 3 ).

When marketable yield was evaluated by regression analysis, $12.8 \%$ of variation was explained by the empirical model. The regression equation was significant, as shown by the $\mathrm{F}$ value (Table 4). As in the case of total yield, marketable yield did not vary significantly between 2014 and 2015 , or between the spring and fall seasons. Similarly, $17.8 \%$ greater yields were observed for the Celebrity cultivar than for Early Girl Bush, although this difference was not statistically significant. Increased marketable yields were obtained from the Beaumont Horticultural Unit location. Marketable yields for this site were $41.6 \%$ greater than the benchmark. Coefficient for total yields from the Beaumont Horticultural Unit site is greater than that for marketable yield, indicating that the increase in marketable yield may be accounted for by the overall increase in yield. Evaluation of pest management strategy with calendar as the benchmark showed much greater marketable yields as a result of management according to the conventional threshold method. Marketable yields from this treatment were $56 \%$ greater than those from the calendar treatment. The organic threshold method resulted in slightly lower marketable yields, although this difference was not significant. Marketable yields for the conventional threshold treatment were in keeping with increased overall yields for this treatment and increase in total yield may account for a large part of the increase in marketable fruit. Although average marketable yields for the organic threshold treatment were $17.9 \%$ lower than for calendar treatments, this trend was not significant. This is somewhat different in comparison with observations of total yield, indicating that direct fruit feeding by insect pests plays an important role in reduction of marketable yields in the organic threshold treatment.

Because of variation in overall yield, the effect of unmarketable fruit weight was examined as a proportion of the total weight harvested from each treatment (Table 5). A lower proportion of fruit was rated unmarketable in 2015 than in 2014. Location did not significantly affect the proportion of fruit rated unmarketable. Season did have a significant 
Table 4. Effect of sample date, season, production year, location, cultivar, and insect pest control treatment on marketable yield of 'Early Girl Bush' and 'Celebrity' tomato in small-scale production in Mississippi.

\begin{tabular}{lcc}
\hline Independent variable & Coefficient & Robust SE \\
\hline Week $^{\mathrm{z}}$ & $0.1425^{* * *}$ & 0.0126 \\
Year $^{\mathrm{y}}$ & $0.1749^{\mathrm{Ns}}$ & 0.1300 \\
Location $^{\mathrm{x}}$ & & \\
Poplarville, MS $_{\text {Beaumont, MS }}$ & $0.2506^{\mathrm{Ns}}$ & 0.1525 \\
Wiggins, MS $_{\text {Season }}^{\mathrm{w}}$ & $0.4159^{*}$ & 0.1889 \\
Cultivar $^{\mathrm{v}}$ & $-0.1320^{\mathrm{Ns}}$ & 0.1625 \\
Method $^{\mathrm{u}}$ & $0.2038^{\mathrm{Ns}}$ & 0.1324 \\
Conventional threshold & $0.1786^{\mathrm{Ns}}$ & 0.1121 \\
Organic threshold $_{\text {Constant }}$ & $0.5603^{* * *}$ & 0.1505 \\
Observations (no.) $_{\text {F value }}$ & $-0.1786^{\mathrm{Ns}}$ & 0.1073 \\
$R^{2}$ & $-0.9447^{* * *}$ & 0.2084 \\
\hline
\end{tabular}

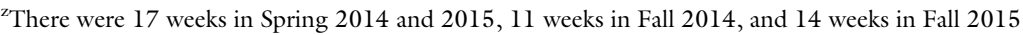

${ }^{\mathrm{y}}$ Benchmark year is 2014 .

${ }^{\mathrm{x}}$ Benchmark location is Kiln, MS

w Benchmark season is spring.

${ }^{\mathrm{v}}$ Benchmark cultivar is Early Girl Bush.

"Benchmark method is Calendar.

NS, ${ }^{*},{ }^{* *},{ }^{* *}$ Nonsignificant or significant at $P \leq 0.05,0.01$, or 0.001 , respectively.

Table 5. Effect of sample date, season, production year, location, cultivar, and insect pest control treatment on proportion of fruit rated unmarketable for 'Early Girl Bush' and 'Celebrity' tomato in small-scale production in Mississippi.

\begin{tabular}{lcc}
\hline Independent variable & Coefficient & Robust SE \\
\hline Week $^{\mathrm{z}}$ & $0.0101^{* * *}$ & 0.0009 \\
Year $^{\mathrm{y}}$ & $-0.0202^{*}$ & 0.0097 \\
Location $^{\mathrm{x}}$ & & \\
Poplarville, MS $_{\text {Beaumont, MS }}$ & $0.0103^{\mathrm{Ns}}$ & 0.0127 \\
Wiggins, MS $_{\text {Season }}^{\mathrm{w}}$ & $0.0155^{\mathrm{Ns}}$ & 0.0140 \\
Cultivar $^{\mathrm{v}}$ & $-0.0188^{\mathrm{Ns}}$ & 0.0153 \\
Method $^{\mathrm{u}}$ & $0.0352^{* *}$ & 0.0122 \\
Conventional threshold & $-0.0175^{*}$ & 0.0085 \\
Organic threshold $^{*}$ & & \\
Constant & $-0.0090^{\mathrm{Ns}}$ & 0.0089 \\
Observations (no.) & $0.0242^{*}$ & 0.0114 \\
F value & $-0.0295^{*}$ & 0.0132 \\
$R^{2}$ & 1,163 & \\
\hline
\end{tabular}

${ }^{\mathrm{z}}$ There were 17 weeks in Spring 2014 and 2015, 11 weeks in Fall 2014, and 14 weeks in Fall 2015.

${ }^{\mathrm{y}}$ Benchmark year is 2014 .

${ }^{\mathrm{x}}$ Benchmark location is Kiln, MS

wenchmark season is spring.

${ }^{\mathrm{v}}$ Benchmark cultivar is Early Girl Bush.

"Benchmark method is Calendar.

NS, * ${ }^{* *},{ }^{* *}$ Nonsignificant or significant at $P \leq 0.05,0.01$, or 0.001 , respectively.

effect on proportion of unmarketable fruit, with $3.5 \%$ more fruit rated unmarketable in the fall season in comparison with spring. Increased insect and disease pressure in the fall may account for the increased proportion of fruit that was unmarketable. Cultivar also resulted in differences in proportion of unmarketable fruit, with
Celebrity resulting in $1.7 \%$ less unmarketable fruit than Early Girl Bush. No difference was observed between proportions of unmarketable fruit for the conventional threshold treatment than for the calendar treatment, which served as the benchmark. Proportion of unmarketable fruit was $2.9 \%$ greater for the organic threshold treatment than for the calendar treatment

EFFECT OF PEST MANAGEMENT STRATEGY ON GROSS VALUE. Gross value, the value of marketable tomatoes at prices indicated by the $\mathrm{Na}$ tional Fruit and Vegetable Retail Report of USDA-AMS for both conventional and organic tomatoes, was analyzed, and $11.9 \%$ of variation was explained by the variables included in the empirical model defined by Eq. [1]. The estimated regression equation was significant, as shown by the $\mathrm{F}$ value (Table 6). Price premiums for organic tomatoes were $60 \%$ in 2014 and $64 \%$ in 2015 (USDA, 2016b). Season and year of production did not significantly affect gross value, although $31.8 \%$ greater gross value was obtained in 2015 as compared with 2014 . Yields within dates were $39.3 \%$ greater in the fall season, although this does not reflect total yield for the seasons, as there were a greater number of harvest dates in spring. Cultivar did not have an effect on gross value of production. Both conventional and organic threshold treatments resulted in significant increases in gross value of production. Production from the conventional threshold treatment was $197 \%$ greater than that from the calendar treatment, whereas production from the organic threshold treatment was $129 \%$ greater.

Cost of pest MANAgement STRATEgIES. Based on linear regression analysis, $22.4 \%$ of variation in total management cost is explained by the variables included in the empirical model defined by Eq. [1]. The estimated regression equation was significant, as shown by the $\mathrm{F}$ value (Table 7). Study year and season did not result in differences in total management cost. Total management cost was not different between tomato cultivars evaluated or locations in this study. Cost of management for the organic threshold treatment was $91.9 \%$ greater than for the calendar treatment, which served as the benchmark. The conventional threshold treatment resulted in a slight decrease in total management cost because of a reduction in the number of spray applications required, although this difference was not significant.

ECONOMIC RETURN FOR PEST MANAGEMENT STRATEgIES. The model used explained $10.5 \%$ of variation in gross margin, defined as the gross 
Table 6. Effect of sample date, season, production year, location, cultivar, and insect pest control treatment on gross value for 'Early Girl Bush' and 'Celebrity' tomato in small-scale production in Mississippi.

\begin{tabular}{|c|c|c|}
\hline Independent variable & Coefficient & Robust SE \\
\hline Week $^{\mathrm{z}}$ & $0.5862 * * *$ & 0.0512 \\
\hline Year $^{\mathrm{y}}$ & $0.3183^{\mathrm{Ns}}$ & 0.5416 \\
\hline \multicolumn{3}{|l|}{ Location $^{\mathrm{x}}$} \\
\hline Poplarville, MS & $0.8343^{\mathrm{Ns}}$ & 0.6392 \\
\hline Beaumont, MS & $1.5678^{*}$ & 0.7731 \\
\hline Wiggins, MS & $-0.6947^{\mathrm{Ns}}$ & 0.7626 \\
\hline Season $^{\mathrm{w}}$ & $0.3939^{\mathrm{Ns}}$ & 0.5337 \\
\hline Cultivar & $0.7077^{\mathrm{Ns}}$ & 0.4654 \\
\hline \multicolumn{3}{|l|}{ Method $^{\mathrm{u}}$} \\
\hline Conventional threshold & $1.9745 * * *$ & 0.5408 \\
\hline Organic threshold & $1.2886^{*}$ & 0.5273 \\
\hline Constant & $-3.6696 * * *$ & 0.8390 \\
\hline Observations (no.) & 1,164 & \\
\hline F value & $16.01 * * *$ & \\
\hline$R^{2}$ & 0.1190 & \\
\hline \multicolumn{3}{|c|}{ 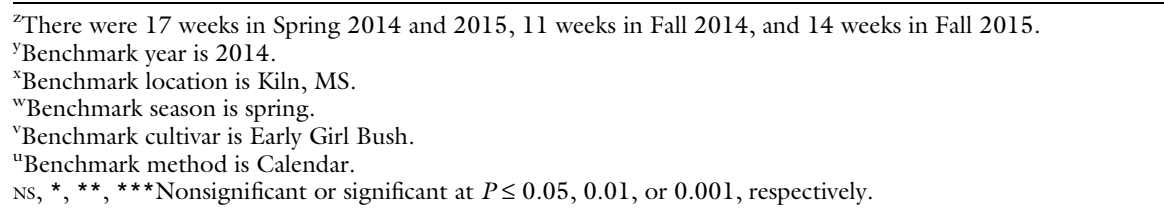 } \\
\hline
\end{tabular}

Table 7. Effect of sample date, season, production year, location, cultivar, and insect pest control treatment on cost of pest management practices for 'Early Girl Bush' and 'Celebrity' tomato in small-scale production in Mississippi.

\begin{tabular}{lcc}
\hline Independent variable & Coefficient & Robust SE \\
\hline Week $^{\mathrm{z}}$ & $0.0483^{* * *}$ & 0.0027 \\
Year $^{\mathrm{y}}$ & $0.0309^{\mathrm{Ns}}$ & 0.0277 \\
Location $^{\mathrm{x}}$ & & \\
Poplarville, MS $_{\text {Beaumont, MS }}$ & $-0.0087^{\mathrm{Ns}}$ & 0.0343 \\
Wiggins, MS $_{\text {Season }}^{\mathrm{w}}$ & $-0.01946^{\mathrm{Ns}}$ & 0.0 .345 \\
Cultivar $^{\mathrm{v}}$ & $-0.0376^{\mathrm{Ns}}$ & 0.0500 \\
Method $^{\mathrm{u}}$ & $0.0295^{\mathrm{Ns}}$ & 0.0273 \\
Conventional threshold & $-0.0308^{\mathrm{Ns}}$ & 0.0249 \\
Organic threshold & & \\
Constant & $-0.0220^{\mathrm{Ns}}$ & 0.0309 \\
Observations (no.) & $0.0919^{* *}$ & 0.0313 \\
F value & $0.0183^{\mathrm{Ns}}$ & 0.0415 \\
$R^{2}$ & 1,164 & \\
\hline
\end{tabular}

${ }^{\mathrm{z}}$ There were 17 weeks in Spring 2014 and 2015, 11 weeks in Fall 2014, and 14 weeks in Fall 2015.

${ }^{\mathrm{y}}$ Benchmark year is 2014 .

${ }^{x}$ Benchmark location is Kiln, MS

${ }^{\mathrm{w}}$ Benchmark season is spring.

${ }^{v}$ Benchmark cultivar is Early Girl Bush.

uenchmark method is Calendar.

Ns, ${ }^{*},{ }^{* *},{ }^{* *}$ Nonsignificant or significant at $P \leq 0.05,0.01$, or 0.001 , respectively.

value less the total cost of pest management practices applied (Table 8). Production year and season did not significantly affect gross margin, although there was a trend for greater gross margins in 2015 when compared with 2014, and for increased gross margin in spring when compared with fall production. Gross margins from the Beaumont Horticultural Unit were greater than those observed at the benchmark Kiln site. Differences in gross margin were not significant among other sites in this study. Although 'Celebrity' resulted in higher gross margins than 'Early Girl Bush', this difference was not statistically significant. Both conventional and organic threshold treatments resulted in greater gross margins in comparison with the calendar spray treatment. As observed for gross value, coefficient for the conventional threshold treatment was much greater than that for organic. Price premiums for organic tomatoes were sufficient to result in greater gross margins, although the effect of increased price was partially counteracted by increased cost of pest management. Conventional threshold pest management resulted in the best results observed among treatments, with a coefficient of 1.997 where calendar served as the benchmark (Table 8 ).

\section{Discussion}

EFFECTS OF CULTIVAR AND PEST MANAGEMENT STRATEGY ON YIELD. Pest management method applied had a significant impact on both total and marketable yields. The conventional calendar treatment produced the lowest total yields observed. Although total yield for tomatoes managed by the organic threshold method was slightly higher than that for the calendar spray treatment, this were not shown to be significantly different. The conventional threshold treatment led to a significant increase in total yields.

Insect damage to plants may be both direct and indirect. Although feeding directly on fruit may reduce marketable yields, feeding on foliage may reduce overall productivity of the plant (Picanço et al., 2007). The increase in total yield for tomatoes treated by the conventional threshold strategy indicates a greater protection afforded the plant throughout the growing season.

Comparisons of yields between pest management systems have generally focused on the effect on amount of marketable fruit. In contrast to the total yields observed in this study, marketable yield from the organic threshold treatment was slightly lower than that observed in the calendar spray treatment. Reports of the effect of organic production have varied, with some studies reporting either no effect or moderate increases to yield (Clark et al., 1999; Drinkwater et al., 1995). Similarly, previous research has concluded that no difference in arthropod damage was observed between conventional and organic production (Drinkwater 
Table 8. Effect of sample date, season, production year, location, cultivar, and insect pest control treatment on gross margin for 'Early Girl Bush' and 'Celebrity' tomato in small-scale production in Mississippi.

\begin{tabular}{|c|c|c|}
\hline Independent variable & Coefficient & Robust SE \\
\hline Week $^{\mathrm{z}}$ & $0.5379 * * *$ & 0.0511 \\
\hline Year $^{y}$ & $0.2874^{\mathrm{Ns}}$ & 0.5406 \\
\hline \multicolumn{3}{|l|}{ Location $^{\mathrm{x}}$} \\
\hline Poplarville, MS & $0.8431^{\mathrm{Ns}}$ & 0.6375 \\
\hline Beaumont, MS & $1.5870 *$ & 0.7721 \\
\hline Wiggins, MS & $-0.6568^{\mathrm{Ns}}$ & 0.7611 \\
\hline Season $^{\mathrm{w}}$ & $0.3647^{\mathrm{Ns}}$ & 0.5361 \\
\hline Cultivarv & $0.7386^{\mathrm{Ns}}$ & 0.4655 \\
\hline \multicolumn{3}{|l|}{ Method $^{\mathrm{u}}$} \\
\hline Conventional threshold & $1.9966 * * *$ & 0.5414 \\
\hline Organic threshold & $1.1968^{*}$ & 0.5270 \\
\hline Constant & $-3.6882 * * *$ & 0.8385 \\
\hline Observations (no.) & 1,164 & \\
\hline F value & $13.68 * * *$ & \\
\hline$R^{2}$ & 0.1049 & \\
\hline
\end{tabular}

${ }^{\mathrm{z}}$ There were 17 weeks in Spring 2014 and 2015, 11 weeks in Fall 2014, and 14 weeks in Fall 2015

${ }^{\mathrm{y}}$ Benchmark year is 2014 .

${ }^{\mathrm{x}}$ Benchmark location is Kiln, MS.

${ }^{\text {w }}$ Benchmark season is spring.

${ }^{\mathrm{v}}$ Benchmark cultivar is Early Girl Bush.

"Benchmark method is Calendar.

NS, ${ }^{*},{ }^{* *},{ }^{* *}$ Nonsignificant or significant at $P \leq 0.05,0.01$, or 0.001 , respectively.

et al., 1995; Letourneau and Goldstein, 2001). Numerous studies and metadata analysis have concluded that organic production results in yield reduction (Crowder and Reganold, 2015; Jans and Fernandez-Cornejo, 2001; Kniss et al., 2016; Nemes, 2009; Riahi et al., 2009). Location and climate may play a significant role in varying yield effects of organic production (Jans and FernandezCornejo, 2001).

Average reduction in yields reported across differing crops and production areas has been reported as varying from $15 \%$ to $33 \%$ (Brumfield et al., 2000; De Ponti et al., 2012; Kniss et al., 2016; Ponisio et al., 2015; Seufert et al., 2012). Among crops studied, greatest yield losses are observed for vegetable crops (De Ponti et al., 2012). Because of the tendency for vegetable crops to be sold on the fresh market without significant processing, there is a low tolerance for cosmetic damage due to insect or disease damage (Kniss et al., 2016). Most studies consider comparisons with a calendar-based approach using either conventional pesticides or conversion to use of only those pesticides meeting organic standards. The use of an action threshold-based approach may be responsible for marketable yields under the organic threshold method more closely matching those from the calendar spray method.

Marketable yields for conventional threshold-based insect pest management were much greater than those observed for both the calendar spray approach and the organic threshold method. Results from other studies conducted regarding yields are mixed. Production using a conventional threshold-based approach has been credited with increased yields in Florida-grown tomato (Pohronezny, 1989); however, studies conducted in California and Brazil indicated no increase in yield due to the adoption of a threshold-based approach to pest management (Picanço et al., 2007; Toscano et al., 1987). In general, the effect of a conventional threshold-based approach has been a slight increase in yields, although this increase is not always significant (Brumfield et al., 1995; Fernandez-Cornejo, 1996; Trumble and Alvarado-Rodriguez, 1993).

Reports have indicated that the gap in yields observed between organic and conventional production is eliminated after 3 years of production (Poudel et al., 2002); however, review of metadata from a large number of studies has indicated that no difference in yields is observed between short- and long-term experiments comparing organic and conventional production. Both increases and decreases have been observed in yields for organic production over time (De Ponti et al., 2012). A major determinant of success in production is the experience of the producer and their decision-making capability (Nemes, 2009). Both the potential of yield reduction under transition from conventional to organic production and the information intensive nature of threshold-based management highlight the importance of effective educational and extension support for producers.

Evaluation of the yield effects of pest insect damage to tomato indicates that direct feeding damage to the fruit is most critical (Picanço et al., 2007). The effect of direct damage to fruit was evaluated in this study by considering the percentage of fruit rated as unmarketable. Both study year and season were shown to have a significant impact. Extent of pest pressure and environmental conditions can vary substantively from year to year and, thus, it can be expected that more damage will be observed in some years than in others. The proportion of fruit rated unmarketable for the fall season was greater than that observed in spring. This is because of an increase in pest pressure during fall seasons. Pest pressure during fall is increased because of two factors. The first factor is an overall increase in pest insect populations for multivoltine species. With additional generations, number of offspring increases, leading to larger populations as the year progresses. The second factor affecting pest populations is the funnel effect. During fall season, fewer crop plants are present in the field, and there are fewer available food resources for pest insects. As a result, pest populations concentrate on the remaining plants. Notably, whitefly populations in Fall 2015 were very high at the Beaumont Horticultural Unit site following harvest of cotton on an adjacent farm. This also partially accounts for the increase in unmarketable fruit at that study location. The percentage of unmarketable fruit was not observed to be different between the calendar-based and conventional threshold methods. The organic threshold treatment resulted in a greater proportion of fruit being rated unmarketable. Organic 
insecticides used in this treatment were less effective in controlling pest populations and had less residual effect, leading to greater amounts of damage observed. This is in keeping with previous observations that the type of insecticide used is a primary factor in affecting populations of pest insects (Hummel et al., 2002). Concerns regarding the buildup of piercing-sucking insects, including whiteflies and the stinkbug complex (Pentatomidae), were confirmed by the observations in this study (Hummel et al., 2002). The most frequent source of damage resulting in fruit being rated as unmarketable was associated with pest insects with piercing-sucking mouthparts, such as stinkbugs and leaf-footed bugs (Leptoglossus sp.). These insects were effectively controlled with the conventional pesticide malathion. Less control was observed for these pests with application of carbaryl under the calendar spray management system. Organic pesticides such as pyrethrin did not provide effective control against these pests, although some degree of control was achieved by application of spinosyn to nymphs of stinkbugs and leaf-footed bugs.

EFFeCTS OF CULTIVAR AND PEST MANAGEMENT STRATEGY ON PRODUCTION COST. When costs of insect pest management were considered for small-scale tomato production in Mississippi, the conventional threshold management method resulted in a slight reduction in overall cost, although this difference was not significant; however, the organic threshold method resulted in significantly increased costs of insect pest management. Impacts of organic production on costs has varied between studies. In some reports, total costs are reportedly similar between organic and conventional production (Crowder and Reganold, 2015; Jans and Fernandez-Cornejo, 2001), whereas in others increased production cost is reported (Brumfield et al., 1995; Pimental et al., 2005). Discussion of costs related to adoption of organic practices must consider the specific crop. Although reductions in costs may be observed in grain crops, most observations of adoption in vegetables indicate adoption of organic production leading to increased costs (Nemes, 2009).

Costs in this study are associated with time spent sampling for insect pest populations as well as the frequency of insecticide applications and amount of specific pesticides used. In the case of the conventional threshold treatment, the process of sampling allowed for an overall reduction in the frequency of insecticide applications, in effect eliminating the cost of labor for those applications. By contrast, in the organic threshold treatment, frequency of spray applications increased. The decline of efficacy and residual activity of insecticides allowed in organic production led to higher cost of production. The need for more frequent applications of organic insecticides has been observed in numerous studies (Brumfield et al., 1995; Kniss et al., 2016; Quarcoo et al., 2017). It has been reported that organic insecticides may be more expensive to purchase than conventional pesticides (Quarcoo et al., 2017). This was not observed in this study for the purchase of insecticides from major retailers.

Labor cost makes up a major component of the overall cost of production. A general consensus exists that adoption of organic practices is more labor intensive than conventional production (Brumfield et al., 1995; Crowder and Reganold, 2015; Pimental et al., 2005). Reports of the extent of increased labor vary from as little as 7\% (Crowder and Reganold, 2015 ) to as much as $35 \%$ (Pimental et al., 2005). Because of the labor associated with sampling, as well as the increase in frequency of pesticide applications, labor costs constitute a significant portion of increase in total cost for the organic threshold treatment observed in this study.

The conventional threshold treatment was similar to the calendar spray treatment in terms of total cost of production. Labor costs associated with sampling counteracted the reduction of costs associated with reduced number of insecticide applications. The reduction in numbers of applications has been observed in previous studies (Fernandez-Cornejo, 1996; Picanço et al., 2007). Adoption of conventional threshold-based pest management was shown to reduce overall costs when evaluated in Mexican tomato production (Trumble and Alvarado-Rodriguez, 1993). The observed decrease in production cost for a conventional threshold-based approach, which was not observed in this study, may be accounted for by the small scale of production.

The impact of production cost must be considered when adoption of a practice is considered. Although attention may be paid to perceived environmental or health benefits, pest management decisions should be based on economic factors (Quarcoo et al., 2017). Because of the reduction in efficacy of allowed pesticides in organic production, insect pest management presents a significant barrier to organic production in Mississippi.

EFFeCTS OF CULTIVAR AND PEST MANAGEMENT STRATEGY ON ECONOMIC RETURN. The pest management practice adopted led to significant differences observed in the gross value received for marketable tomatoes. This represents the value of production without consideration of the cost of management. In both conventional and organic thresholdbased management, gross value was greater than for the calendar approach. Increases in gross value can be attributed to different sources in the case of conventional and organic threshold-based management. In the case of threshold-based management using conventional pesticides, increases in the marketable yield led to much greater gross value obtained. For organic threshold-based management, a slight decrease in yield was observed. However, due to application of price premiums to the value of organic fruit in this treatment, the gross value of production was increased above that of the calendar approach. Increased efficacy of pesticides used in conventional production, and when used in response to an observed action threshold, led to much greater gross returns despite the reduced prices received for conventionally grown tomatoes.

Evaluation of the impact of insect pest management practice must consider the cost of that practice. Gross margin includes the gross value of production less the total cost of insect pest management, including labor and materials cost. In this study, price premiums resulted in greater production value for organic threshold-based management in comparison with the calendar spray approach. High premiums for organically grown tomatoes allowed for greater return despite lower marketable yields and increased production cost. Increased 
marketable yields resulting from the conventional threshold-based insect pest management treatment were sufficient to provide substantively greater economic return than either the calendar-based or organic threshold-based methods. Applications of conventional insecticides in response to action thresholds led to more effective management of pest insects, which in turn led to much greater marketable yields. Although price premiums evaluated in this study were high, they were insufficient to counteract the decline in yield in comparison with a conventional thresholdbased approach.

Previous research comparing a calendar-based approach to insect pest management and organic production have indicated that price premiums are sufficient to lead to an increase in economic return for organic production (Brumfield et al., 2000; Cavigelli et al., 2009; Crowder and Reganold, 2015; Nemes, 2009). Studies comparing organic pesticide use have not generally included use of action thresholds for insecticide applications. Comparison of a conventional threshold-based approach with application of organic insecticides without thresholds led to reduction in economic return with price premiums of $30 \%$ (Brumfield et al., 1995; Picanço et al., 2007). Both conventional and organic thresholdbased management led to increases in gross margin for small-scale tomato production in Mississippi. Because of insecticide efficacy and residual control, returns from the conventional threshold pest management method were much greater than those for use of organic insecticides.

Comparisons of conventional and organic production must consider both the crop grown and the location of production. Previous reports have indicated that returns for organic production are strongest in grain and cereal crops, and lowest in vegetable crops (Crowder and Reganold, 2015; Kniss et al., 2016; Nemes, 2009; Ponisio et al., 2015; Seufert et al., 2012). Low tolerances for damage in fresh market products is a major barrier to organic vegetable production (Kniss et al., 2016). Comparison of organic and conventional production in regions with high temperatures and humidity, which are more favorable to pest insects, with areas with more moderate climates is difficult (Fernandez-Cornejo et al., 1998; Kniss et al., 2016). Due to increased pest pressure, yield and economic return in Mississippi may be particularly responsive to improved pest management practices.

Another factor of location that must be considered for adoption of pest management practices is the ability to receive premium prices for organic produce. Consumer demand and willingness to pay premiums is a major element in determining profitability for organic vegetables (Nemes, 2009; Quarcoo et al., 2017; Wynen, 2006). Organic producers must be located near highincome populations both willing and capable of paying premiums (Brumfield et al., 1995). Further development of organic production practices to reduce costs and improve yields in comparison with conventional production could improve the profitability of organic farms. Despite perception of environmental or health benefits associated with organic production, adoption of this practice will be limited unless economic returns can be made comparable to production according to conventional practices (Nemes, 2009).

Greater returns for the conventional threshold-based management strategy indicate that adoption of action thresholds and the use of recommended conventional pesticides, important components of a complete IPM strategy, has the potential to increase yields and economic return for small-scale vegetable producers in Mississippi. Previous works also have shown increased profitability for adoption of this strategy (Brumfield et al., 1995). Adoption of this strategy allows producers to reduce insecticide applications, and potentially environmental and health concerns, while maintaining or improving economic outcomes (Brumfield et al., 1995; Fernandez-Cornejo et al., 1998).

ECONOMY OF SCALE. A consideration for economic impact of management strategies for vegetable production is effect of scale. In terms of practices considered in this study, costs associated with labor related to insecticide applications and direct cost of insecticides applied increase along with increase in area. At significantly greater areas of production, additional production equipment may reduce pesticide application times; however, sampling recommendations for field tomato vary significantly by location, with recommendations in Florida being 6 to 10 contiguous plants in a 2 acre grid of the field (Schuster and Smith, 2015), and those in Maryland being 10 plants at five to eight sites within a field (Brust, 2013). Sampling recommendations for Alabama are 10 plants be sampled at five sites throughout the field (Sikora, 2000). Number of tomato plants per field varies according to plant spacing. For the purpose of evaluating effect of these strategies at the scale of 1 acre, a row spacing of $6 \mathrm{ft}$ and within row spacing of 8 inches will be used, leading to a total of 4840 plants /acre (Kelley and Boyhan, 2006). As scale of production increases, labor costs for time spent sampling decrease in importance because of a smaller proportion of plants in the field being sampled. Costs for insecticide applications increase significantly in terms of both labor cost and amount of materials applied. In the case of recommendations from Alabama, number of plants sampled, and thus labor for sampling would increase by a factor of 12.5 in comparison with time spent in this study. At the previously described estimated number of plants per acre, time and materials costs of insecticide application would increase by a factor of 605 . Avoidance of pesticide applications due to use of thresholds would represent a greater cost saving effect as scale of production increases. Additional production costs for labor related to field preparation, maintenance, harvesting, marketing, and other factors as well as a cultivar of other cost factors would affect actual production value.

Cost benefit analysis is important to adoption of pest management practices to ensure that those practices are economically beneficial (Quarcoo et al., 2017). Observations of this study suggest that adoption of a threshold-based insect pest management strategy using conventional pesticides would represent a potential for increased yields and economic return for small-scale vegetable producers in Mississippi. Similarly, organic production has the potential for providing increased value of production. Organic production would be best suited to conditions in which both price premiums can be obtained and there is a desire in the market to 
obtain organic products regardless of those premiums. Having an established market has potential to decrease waste, which may be a significant issue in sale of fresh market tomatoes. Improved economic outcomes for conventional threshold-based production is also supported in that conventional producers are able to adopt those organic practices that are shown to increase profitability, whereas organic producers are limited by organic standards (Jans and Fernandez-Cornejo, 2001). Adoption of threshold-based pest management systems by smallscale producers is limited. Identification and mitigation of barriers to adoption would be economically beneficial to these producers. Application of economic thresholds requires extensive understanding of crop market values, as well as the cost and efficacy of control actions in reducing yield loss. Because of the complexity of economic thresholds and variability in the factors required for their calculation, action thresholds have been developed to indicate when controls should be applied. Development and distribution of information related to action thresholds and sampling regimens for small-scale production would be valuable.

This study examined the use of action thresholds and adoption of thresholds in terms of their effect on yields and economic return for smallscale tomato production. These factors represent one aspect of crop management, and full understanding of the yield and economic effects of management strategies must also include factors such as disease, weed, and nutritional management. Further research evaluating these factors individually and in combination as a complete agroecosystem will be needed to provide thorough strategies for economically viable small-scale production of vegetables in Mississippi.

\section{Literature cited}

Allen, W. and E. Rajotte. 1990. The changing role of extension entomology in the IPM era. Annu. Rev. Entomol. 35(1):379-397.

Barker, K.R. and C. Sorenson. 2003. Cropping systems and integrated pest management. J. Crop Prod. 8(1-2):271-305.

Bureau of Labor Statistics. 2015. Occupational employment statistics. 3 Dec. 2015. <https://www.bls.gov/oes/tables.htm>.
Brumfield, R., F. Adelaja, and S. Reiners. 1995. Economic analysis of three tomato production systems. Acta Hort. 340:255260.

Brumfield, R., A. Rimal, and S. Reiners. 2000. Comparative cost analysis of conventional, integrated crop management, and organic methods. Hort Technology 10:785-793.

Brust, G. 2013. Insect pests of tomato. 12 Jan. 2016. <https://extension.umd.edu/ learn/insect-pests-tomato $>$.

Cavigelli, M.A., B. Hima, J. Hanson, J. Teasdale, and Y. Lu. 2009. Long-term economic performance of organic and conventional field crops in the mid-Atlantic region. Renew. Agr. Food Syst. 24(2):102-119.

Clark, S., K. Klonsky, P. Livingston, and S. Temple. 1999. Crop-yield and economic comparisons of organic, low-input, and conventional farming systems in California's Sacramento Valley. Amer. J. Altern. Agr. 14(3):109-121.

Crowder, D. and J. Reganold. 2015. Financial competitiveness of organic agriculture. Proc. Natl. Acad. Sci. USA 112(24):76117616.

DeLind, L.B. 2011. Are local food and the local food movement taking us where we want to go? Or are we hitching our wagons to the wrong stars? Agr. Human Values 28(2):273-283.

De Ponti, T., B. Rijk, and M. van Ittersum. 2012. The crop yield gap between organic and conventional agriculture. Agr. Syst. 108(C):1-9.

Drinkwater, L., D. Letourneau, F. Workneh, A. van Bruggen, and C. Shennan. 1995. Fundamental differences between conventional and organic tomato agroecosystems in California. Ecol. Appl. 5(4):1098-1112.

Fernandez-Cornejo, J. 1996. The microeconomic impact of IPM adoption: Theory and application. Agr. Resour. Econ. Rev. 25(2):149-160.

Fernandez-Cornejo, J., S. Jans, and M. Smith. 1998. Issues in the economics of pesticide use in agriculture: A review of the empirical evidence. Rev. Agr. Econ. 20(2):462-488.

Herms, D.A. 2004. Using degree-days and plant phenology to predict pest activity, p. 59-59. In: V. Krischik and J. Davidson (eds.). IPM of Midwest landscapes. Univ. Minnesota, St. Paul.

Hummel, R., J. Walgenbach, D. Hoyt, and G. Kennedy. 2002. Effects of production system on vegetable arthropods and their natural enemies. Agr. Ecosyst. Environ. 93(1-3):165-176.
Jans, S. and J. Fernandez-Cornejo. 2001. The economics of organic farming in the U.S.: The case of tomato production. Amer. Agr. Econ. Assn. Annu. Mtg., 5-8 Aug. 2001, Chicago, IL.

Kelley, W. and G. Boyhan. 2006. UGA commercial tomato production handbook. 12 Jan. 2016. <http://extension.uga.edu/ publications/detail.html?number $=\mathrm{B} 1312>$.

Kniss, A., S. Savage, and R. Jabbour. 2016. Commercial crop yields reveal strengths and weaknesses for organic agriculture in the United States. PLoS One 11(11):e0165851.

Kogan, M. 1998. Integrated pest management: Historical perspectives and contemporary developments. Annu. Rev. Entomol. 43(1):243-270.

Lamichhane, J., S. Dachbrodt-Saaydeh, P. Kudsk, and A. Messéan. 2016. Towards a reduced reliance on conventional pesticides in European agriculture. Plant Dis. 100(1):10-24.

Letourneau, D. and B. Goldstein. 2001. Pest damage and arthropod community structure in organic vs. conventional tomato production in California. J. Appl. Ecol. 38(3):557-570.

Layton, B. 2016. Insect pests of the home vegetable garden. Mississippi State Univ. Ext. Publ. P2347. 4 Mar. 2016. <https:// extension.msstate.edu/sites/default/ files/publications/publications/p2347_1. pdf $>$.

Ling, P. 1994. Introduction: From mechanization to the information highway, p. 5-8. In: NRAES, greenhouse systems: Automation, culture and environment, Proc. Greenhouse Systems Intl. Conf., 20-22 July 1994, New Brunswick, NJ.

Lowe's Companies, Inc. 2014. Pesticides. 12 Mar. 2014. <www.lowes.com/pl/ Pesticides-Insect-pest-control-Outdoors>.

Lucas, J. 2011. Advances in plant disease and pest management. J. Agr. Sci. 149(1):91114.

Majumdar, A., A. Chambliss, N. Kelly, J. Miles, G. Gray, C. Becker, G. McQueen, and L. Chapman. 2014. Tomato insect pests and scouting methods. Alabama Coop. Ext. System. Publ. ANR-2206.

Nagel, D., B. Layton, A. Henn, and M. Burnham. 2014. Garden tabloid. Mississippi State Univ. Ext. Publ. P1091. 4 May 2017. <http://extension.msstate.edu/sites/ default/files/publications/publications / p1091.pdf>.

Nemes, N. 2009. Comparative analysis of organic and non-organic farming systems: A critical assessment of farm profitability. FAO, Rome, Italy. 
Picanço, M.C., L. Bacci, A. Crespo, M. Miranda, and J. Martins. 2007. Effect of integrated pest management practices on tomato production and conservation of natural enemies. Agr. For. Entomol. 9(4):327-335.

Pimental, D., P. Hepperly, J. Hansen, S. Douds, and R. Seidel. 2005. Environmental, energetic, and economic comparisons of organic and conventional farming systems. Bioscience 55(7):575-582.

Pohronezny, K. (ed.). 1989. The impact of integrated pest management on selected vegetable crops in Florida. Agr. Expt. Sta., Univ. Florida, Inst. Food Agr. Expt. Sta. Bul. 875.

Ponisio, L., L. M'Gonigle, K. Mace, J. Palomino, P. de Valpine, and C. Kremen. 2015. Diversification practices reduce organic to conventional yield gap. Proc. Biol. Sci. 282:20141396.

Poudel, D., W. Horwath, W. Lanini, S. Temple, and A. van Bruggen. 2002. Comparison of soil $\mathrm{N}$ availability and leaching potential, crop yields and weeds in organic, low-input and conventional farming systems in northern California. Agr. Ecosyst. Environ. 90(2):125-137.

Posadas, B. 2018a. Tomato growers in Mississippi. 26 Aug. 2018. <https:// hortmarine.wordpress.com/2018/08/ 23/tomato-growers-in-mississippi/>.

Posadas, B. 2018b. Socioeconomic determinants of the level of mechanization of nurseries and greenhouses in the southern United States. AIMS Agr. Food $3(3): 229-245$.

Pujari, D., B. Bhattacharyya, and M. Das. 2013. Insect pest management in organic agriculture. Intl. J. Plant Prot. 6(2):467472 .
Quarcoo, F., C. Bonsi, D. Nii, O. Tackie, W. Hill, and G. Wall. 2017. Economies of scale in integrated pest management in vegetable and fruit production. Professional Agr. Workers J. 5(7):53-68.

Riahi, A., C. Hdiner, M. Sanaa, N. Tarchoun, M. Kheder, and N. Guezal. 2009. Effect of conventional and organic production system on the yield and quality of field tomato cultivars grown in Tunisia. J. Sci. Food Agr. 89(13):2275-2282.

Rogers, W. 1993. Regression standard errors in clustered samples. Stata Tech. Bull. 3(13):19-23.

Saberfar, F. and G. Sheikhi. 2009. Influence of phenological and physical characters of tomato on fruit borer, $\mathrm{Hel}$ icoverpa armigera (Hubner) infestation. Resistance Pest. Mgt. Nwsl. 19(1):46-47.

Schuster, D. and H.A. Smith. 2015. Scouting for insects, use of thresholds, and conservation of beneficial insects on tomatoes. 2 Feb. 2014. <http://edis.ifas. ufl.edu/in482>.

Seufert, V., N. Ramakutty, and J. Foley. 2012. Comparing the yields of organic and conventional agriculture. Nature 485(7397):229-232.

Sikora, E. 2000. Tomato insect management guide for Alabama. 9 Feb. 2016. <http://www.aces.edu/pubs/docs/A/ ANR-1191/ANR-1191.pdf>.

The Home Depot, Inc. 2014. Pest control at the Home Depot. 12 Mar. 2014. $<$ www.homedepot.com/b/OutdoorsGarden-Center-Insect-Pest-Control>

Toscano, N., R. Youngman, E. Oatman, P. Phillips, M. Jimenez, and F. Mufioz. 1987. Implementation of an integrated pest management program for fresh market tomatoes. Appl. Agr. Res. 1(5):315324.
Trumble, J. and B. Alvarado-Rodriguez. 1993. Development and economic evaluation of an IPM program for fresh market tomato production in Mexico. Agr. Ecosyst. Environ. 43(3):267-284.

U.S. Department of Agriculture. 2016a. Materials for organic crop production. 2 Dec. 2016. <https://www.ams.usda.gov/ sites/default/files/media/NOP-5034-1. pdf $>$.

U.S. Department of Agriculture. 2016b. National fruit and vegetable retail report. 4 Mar. 2014. <http://www.ams.usda.gov/ mnreports/fvwretail.pdf>.

U.S. Department of Agriculture. 2017. 2017 Census of agriculture. Mississippi state and county data volume 1. Geographic area series: Part 24. 12 July 2019. <https:// www.nass.usda.gov/Publications / AgCensus/2017/Full_Report/Volume_ 1,_Chapter_2_US_State_Level/st99_2_ 0024_0024.pdf>.

Walmart Inc. 2014. Insecticides. 18 Mar. 2014 <www.walmart.com/c/kp/ insecticides $>$.

Waluniba, and A. Alemla Ao. 2014. Seasonal incidence of insect-pests in tomato (Lycopersicon esculantum M.) on different planting dates and its correlation with abiotic factors. Intl. J. Bio-resource Stress Mgt. 5(2):280-284.

Wynen, E. 2006. Economic management in organic agriculture, p. 231-241. In: P. Kristiansen, A. Taji, and J.P. Reganold (eds.). Organic agriculture-A global perspective. CSIRO Publ., Melbourne, Australia.

Yurk, B. and J. Powell. 2010. Modeling the effects of developmental variation on insect phenology. Bull. Math. Biol. 72(6):1334-1360. 